\title{
FORMULASI DAN PENGARUH KONSENTRASI ASAM SITRAT, ASAM \\ TARTRAT DAN NATRIUM BIKARBONAT TERHADAP SIFAT GRANUL EFFERVESCENT EKSTRAK LABU KUNING (Cucurbita maxima Duch)
}

\author{
Yazid Hayaza ${ }^{1}$, Agitya Resty Erwiyani² ${ }^{2}$ Jatmiko Susilo $^{3}$ \\ Program Studi Farmasi, Universitas Ngudi Waluyo, Ungaran \\ Email : yazid.hayaza@gmail.com
}

\begin{abstract}
ABSTRAK
Labu kuning (Cucurbita maxima Duch) telah diteliti memiliki aktifitas antioksidan untuk membantu melawan berbagai macam radikal bebas yang masuk ke dalam tubuh dan sangat baik untuk meningkatkan daya tahan tubuh serta memperlambat proses penuaan. Penelitian ini bertujuan untuk mengetahui pengaruh perbedaan formulasi granul effervescent ekstrak labu kuning (Cucurbita maxima Duch) terhadap sifat fisik granul yang dibuat dengan metode granulasi basah. Rancangan penelitian menggunakan penelitian eksperimental yaitu pembuatan formulasi sediaan efervesen ekstrak daging buah labu kuning (Cucurbita maxima Duch) dengan variasi konsentrasi asam sitrat, asam tartarat dan natrium bikarbonat dan uji sifat fisik granul meliputi : kadar air, volume guncang, waktu alir, waktu disperse dan $\mathrm{pH}$. Pada formulasi I, didapatkan hasil pengujian kadar air $0.49 \%$, volume guncang 9\%, kecepatan alir 16,37 gram/detik, waktu dispersi selama 78 detik dan $\mathrm{pH}$ 6.31, Pada formulasi II, didapatkan hasil pengujian kadar air $0.54 \%$, volume guncang $4.44 \%$, kecepatan alir 22.37 gram/detik, waktu dispersi selama 56 detik dan pH 6.03, Sedangkan pada formulasi III didapatkan hasil pengujian kadar air $0.64 \%$, volume guncang 3.25\%, kecepatan alir 25.92 gram/detik, waktu dispersi selama 45 detik dan $\mathrm{pH}$ 5.31. Pada formulasi variasi jumlah asam sitrat dan asam tartrat dan natrium bikarbonat berpengaruh terhadap kadar air, volume guncang, kecepatan alir, waktu dispersi dan $\mathrm{pH}$ granul effervescent ekstrak daging buah labu kuning (Cucurbita maxima Duch).
\end{abstract}

\section{Kata Kunci : Labu Kuning (Cucurbita maxima Duch), Formulasi effervescent, Granulasi basah.}

\section{ABSTRACT \\ Formulation and Concentration Effect of Citric Acid, Tartratic Acid and Sodium Bicarbonate t the Granul Effervescent Character of Pumpkin Extract (Cucurbita Maxima Duch}

Pumpkin (Cucurbita maxima Duch) has antioxidant activity to help fight various kinds of free radicals that enter the body and is very good for increasing endurance and slowing down the aging process. To determine the effect of different formulations of effervescent granules of pumpkin extract (Cucurbita maxima Duch) on the physical properties of granules made with wet granulation method. The design of the study used experimental research which was a formulation of effervescent preparations of pumpkin extract (Cucurbita maxima Duch) with variations in the concentration of citric acid, tartaric acid and sodium bicarbonate and testing the physical properties of granules including: water content, shaking volume, flow rate, time disperse and $\mathrm{pH}$. In formulation I, the results obtained water content of 0.49\%, shaking volume 9\%, flow Formulasi dan Pengaruh.. (Yazid Hayaza, Agitya Resty Erwiyani, Jatmiko Susilo) 
rate 16.37 grams / second, dispersion time 78 seconds and $p H$ of 6.31, In formulation II, the test results showed a moisture content of $0.54 \%$, volume shaking $4.44 \%$, flow rate of 22.37 gram / second, dispersion time for 56 seconds and $p H$ 6.03, while in formulation III the results of water content of 0.64\%, shaking volume of $3.25 \%$, flow rate 25.92 grams / second, dispersion time for 45 seconds and pH 5.31. In the formulation of variations in amount of citric acid and tartaric acid and sodium bicarbonate affect water content, shaking volume, flow rate, dispersion time and $p H$ of effervescent granules extract of pumpkin (Cucurbita maxima Duch).

\section{Keywords : Pumpkin (Cucurbita maxima Duch), Effervescent Formulation, Wet Granulation.}

\section{PENDAHULUAN}

Radikal bebas bertanggung jawab terhadap berbagai macam penyakit termasuk kanker, penyakit jantung, kelainan syaraf, penyakit Alzheimer, parkinson, liver, penuaan dini dan kelainan pada tulang belakang, perlindungan terhadap radikal bebas dapat diperoleh dengan menggunakan antioksidan (Alam, dkk, 2013). Antioksidan adalah penghambat proses oksidasi, bahkan pada konsentrasi yang relatif kecil memiliki peran fisiologis yang beragam dalam tubuh, Kandungan antioksidan dari bahan tanaman bertindak sebagai bahan penangkap radikal, dan membantu dalam mengubah radikal menjadi kurang reaktif. Berbagai antioksidan penangkal radikal bebas ditemukan dalam sumber makananseperti buah-buahan, sayuran dan teh, dll (Kumar,2014).

Labu kuning (Cucurbita moschata durch) merupakan sayuran penting karena nilai nutrisinya dan menfaat kesehatannya. Tanaman ini adalah sumber karetonoid yang kaya vitamin larut air, fenolat, flavonoid polisakarida, garam mineral dan vitamin yang semuanya bermanfaat bagi kesehatan (Aukkanit dan sirichokworrakit, 2017). Labu kuning termasuk dalam keluarga Cucurbitaceae dan dibudidayakan di daerah yang hangat di seluruh dunia. Tanaman ini tumbuh tidak hanya sebagai tanaman pangan tapi juga untuk makanan hewani (Riaz, dkk, 2015).

Formulasi yang tepat dalam pengolahan bahan alam menjadi suatu bentuk sediaan yang mudah diterima masyarakat diharapkan dapat meningkatkan kepraktisan dan minat masyarakat dalam mengkonsumsi obat bahan alam. Salah satu upaya untuk meningkatkan kepraktisan dan minat masyarakat tersebut ialah dengan membuat labu kuning dalam bentuk ekstrak dan dan selanjutnya diformulasikan dalam bentuk sediaan granul effervescent. Sediaan granul effervescent merupakan campuran senyawa asam dan basa bila ditambahkan dengan air akan bereaksi membebaskan karbondioksida, sehingga menghasilkan buih. Larutan karbonat yang dihasilkan dapat menutupi rasa garam atau rasa lain yang tidak diinginkan dari zat obat. Selain itu, sediaan ini dalam hal tertentu relatif memiliki keuntungan dibanding untuk sediaan lain (Krysta, 2016).

Beberapa keuntungan sediaan effervescent yaitu penyimpanan larutan dalam waktu seketika, penggunaannya lebih mudah, dapat diberikan kepada orang yang mengalami kesulitan menelan tablet atau kapsul dan bentuk granul effervescent akan larut dengan lengkap dalam air sehingga lebih mudah untuk diabsorbsi dan adanya karbonat dapat memberikan rasa yang menyegarkan (Ansel, 1989). 
Berdasarkan hal tersebut maka pada penelitian ini akan dibuat formulasi dan pengaruh konsentrasi asam sitrat, asam tartarat dan natrium bikarbonat terhadap sifat granul effervescent ekstrak labu kuning (Cucurbita moschata durch). Penelitian ini memiliki tujuan untuk meneliti pengaruh variasi konsentrasi asam sitrat, asam tartarat dan natrium bikarbonat terhadap sifat granul efervesen ekstrak labu kuning (Cucurbita maxima durch), menganalisis pengaruh variasi konsentrasi asam sitrat, asam tartarat dan natrium bikarbonat terhadap kadar air, volume guncang, waktu alir, waktu dispersi, dan $\mathrm{pH}$ granul efervesen, dan untuk mengetahui formula berapa yang memenuhi persyaratan sediaan granul efervesen paling optimal.

\section{METODE PENELITIAN}

Jenis penelitian ini adalah penelitian eksperimental, yaitu dengan memberikan perlakuan terhadap subyek penelitian yang dapat mempengaruhi perubahan pada variabel yang akan diteliti. Penelitian eksperimen yaitu suatu penelitian yang berusaha mencari pengaruh variabel tertentu terhadap variabel yang lain dalam kondisi yang terkontrol secara ketat. Variabel independennya dimanipulasi oleh peneliti (Susilani, 2015). Penelitian ini merupakan penelitian kasual (sebab akibat) yang pembuktiannya diperoleh melalui komparasi/perbandingan.

Ekstrak Labu Kuning

(Cucurbita maxima durch) adalah ekstrak kering yang diperoleh dengan maserasi menggunakan etanol $96 \%$. Granul adalah kumpulan dari serbuk yang menggumpal dan menjadi pertikel tunggal yang digranulasi menggunakan metode granulasi basah. Effervescent adalah granul atau serbuk kasar sekali mengandung unsur obat dalam campuran kering, yang terdiri dari natrium bikarbonat, asam sitrat dan asam tartarat. Kadar air dalah banyaknya air yang terkandung dalam sediaan yang dinyatakan dalam persen. Kadar air dari sampel dilihat menggunakan alat moisture meter pada temperatur $105{ }^{\circ} \mathrm{C}$ selama 5 menit. Syarat kadar air yang baik adalah $0,4 \%$ - 0,7\% (Lestari., 2014).

Volume tuang adalah cara untuk menentukan ukuran partikel dan bentuk partikel granul dengan alat timbangan analitik dan gelas ukur, volume yang terbaca dibagi massa granul $(\mathrm{ml} / \mathrm{g})$ menggambarkan volume tuang. Volume tuang yang baik adalah volume tuang $>$ bobot granul. Daya alir granul adalah kemampuan granul untuk mengalir pada alat kempa, metode untuk melihat daya alir granul ialah metode corong dan metode sudut diam. Metode corong dilakukan dengan menghitung waktu granul melewati corong kemudian dihitung daya alirnya (gram/detik) daya alir yang baik adalah $>4$. Sedangkan metode sudut diam dilakukan dengan menghitung sudut granul yang dijatuhkan dari corong (sudut istirahat) jika $\alpha \leq 30^{\circ}$ menunjukkan granul dapat mengalir bebas.

Waktu dispersi adalah waktu yang dibutuhkan granul untuk larut di dalam air dengan sempurna. Volume air yang digunakan ialah $250 \mathrm{ml}$ dengan suhu 15-25 ${ }^{\circ} \mathrm{C}$, persyaratan granul terdispersi dengan sempurna ialah $<5$ menit. Uji $\mathrm{pH}$ atau derajar keasaman digunakan untuk menyatakan tingkat keasaman larutan. Pengukuran $\mathrm{pH}$ dilakukan dengan alat $\mathrm{pH}$ meter, $\mathrm{pH}$ terbaik merupakan $\mathrm{pH}$ yang memiliki selisih terkecil dengan standar $\mathrm{pH}$ untuk produk minuman, yaitu 7 (Menkes, 2010).

Data disajikan dalam bentuk tabel berisi hasil uji kualitas sediaan fisik granul effervescent meliputi uji kadar air, volume tuang, daya alir (metode corang dan sudut diam), waktu dispersi dan uji $\mathrm{pH}$ dan dibandingkan dengan 
persyaratan sediaan granul effervescent. Persyaratan untuk kadar air ialah 0,4 0,7\% (Lestari., 2014), volume guncang $\leq 20 \%$, metode corong $>4 \mathrm{~g} /$ detik (Aulton., 1988), waktu dispersi < 5 menit (Siregar dan Wikarsa., 2010), dan $\mathrm{pH}$ ialah yang memiliki selisih terkecil dari 7 (Menkes., 2010). Data yang diperoleh dari pengujian kadar air, volume tuang, daya ali, waktu dispersi dan $\mathrm{pH}$ dianalisis secara statistik menggunakan program pengolahan data statistik SPSS yang meliputi uji normalitas, uji homogenitas dan uji parametrik (One-Way ANOVA dan Kruskal Wallis) (Andriani, 2016). Dilakukuan juga uji T-Hitung untuk melihat pengaruh bahan secara parsial.

\section{HASIL DAN PEMBAHASAN}

Penyarian dari daging buah labu kuning dilakukan dengan menggunakan metode maserasi. Maserasi adalah proses pengekstrakan simplisia menggunakan pelarut dengan beberapa kali pengocokan atau pengadukan pada temperatur kamar (Depkes, 2000). Pelarut penyari yang digunakan adalah etanol 96\%. Pemilihan pelarut berdasarkan pada tingkat keamanan dan kemudahan saat menguapkan. Pelarut etanol dipilih karena etanol merupakan pelarut yang bersifat polar yang dapat menarik senyawa flavonoid pada labu kuning yang bersifat polar. Serta didasarkan pada penelitian sebelumnya yang membandingkan pelarut etanol $70 \%$ dan 90\%. Hasil penelitian menunjukkan maserasi dengan pelarut etanol $96 \%$ menghasilkan rendemen tertinggi yaitu 37,11\% dan IC50 sebesar $168,78 \mu \mathrm{g} / \mathrm{mL}$ (Yulia, 2014). Hasil ekstrak kental daging buah labu kuning (Cucurbita maxima Duch) diperoleh sebanyak 163,518 gram dengan rendemen $16,351 \%$.

Pembuatan ekstrak labu kuning (Cucurbita maxima Duch) menggunakan metode ekstraksi cara dingin dengan cara maserasi dan menggunakan pelarut etanol $96 \%$. Diharapkan senyawa-senyawa yang terdapat didalam daging buah labu kuning dapat tersari secara sempurna. Pemeriksaan organoleptik merupakan pemeriksaan yang dilakukan menggunakan panca indra untuk mendeskripsikan bentuk, warna, bau dan rasa ekstrak yang diperoleh. Tujuan pemeriksaan ini adalah untuk identifikasi awal ekstrak secara sederhana. Organoleptik merupakan parameter spesifik dari suatu ekstrak (Depkes RI, 2000). Ekstrak daging buah labu yang diperoleh berbentuk kental, berwarna coklat kemerahan, bau manis khas labu dan rasanya manis. Bobot total ekstrak yang diperoleh sebanyak 163,518 gram atau diperoleh rendemen sebanyak 16,351\%.

Formulasi granul efervesen juga digunakan kombinasi dua macam asam yaitu asam sitrat dan asam tartrat Terbentuknya granul pada pembuatan sediaan effervescent lebih disebabkan oleh adanya satu molekul air kristal pada setiap molekul asam sitrat (Voight, 1995). Penggunaan asam tartrat dimaksudkan untuk mencapai konsentrasi asam yang ekivalen pada saat reaksi effervescent yang tidak mungkin dicapai oleh pemakaian asam sitrat secara tunggal, karena sifat asam sitrat triprotik (Siregar, 2010).

Tabel 3.1 Hasil Uji Kadar Air

\begin{tabular}{cccccc}
\hline Uji & $\begin{array}{c}\text { Formula } \\
\text { II }\end{array}$ & $\begin{array}{c}\text { Formula } \\
\text { III }\end{array}$ & $\begin{array}{c}\text { Formula } \\
\text { III }\end{array}$ & persyaratan & $\begin{array}{c}\text { Uji } \\
\text { Anova }\end{array}$ \\
\hline Kadar Air & 0,49 & 0,54 & 0,64 & $0,4-0,7 \%$ & P-Value \\
SD & 0,025 & 0,020 & 0,023 & (Lestari, 2014) & 0,000 \\
\hline $\begin{array}{c}\text { Volume } \\
\text { Guncang }\end{array}$ & $9,00 \%$ & $4,44 \%$ & $3,75 \%$ & $\leq 20 \%$ (Voight, & p-Value \\
$1995)$ & 0,000
\end{tabular}




\begin{tabular}{cccccc}
\hline Uji & $\begin{array}{c}\text { Formula } \\
\text { II }\end{array}$ & $\begin{array}{c}\text { Formula } \\
\text { III }\end{array}$ & $\begin{array}{c}\text { Formula } \\
\text { III }\end{array}$ & persyaratan & $\begin{array}{c}\text { Uji } \\
\text { Anova }\end{array}$ \\
\hline SD & 1,22 & 1,11 & 0,68 & & \\
\hline Waktu Alir & 16,37 & 22,37 & 25,92 & $\geq 10 \mathrm{~g} / \mathrm{s}$ & p-Value \\
SD & 1,27 & 2,27 & 3,52 & (Aulton, 1988) & 0,000 \\
\hline Waktu & $1: 12,80$ & $0: 55,60$ & $0: 44,80$ & $<5$ menit & P-Value \\
Dispersi & $0: 7,190$ & $0: 6,348$ & $0: 4,207$ & (Siregar, 2010) & 0,000 \\
SD & 6,31 & 6,03 & 5,31 & Mendekati 7 & p-Value \\
pH & 0,046 & 0,076 & 0,021 & (Menkes, 2010) & 0,002 \\
SD & & & & &
\end{tabular}

Penyerapan air atau uap ini dapat menggunakan kapur aktif, asam sulfat, silica gel, klorida, kalium hidroksid, kalium sulfat atau bariumoksida (Sudarmadji, 2010). Pada pengujian kadar air, diperoleh formula I $0,49 \%$, formula II $0,54 \%$ dan formula III $0,64 \%$. Hasil ini menunjukkan kadar air dari semua formula memenuhi persyaratan untuk kadar air granul efervesen yaitu $0,4-0,7 \%$. Kadar air yang tinggi berkaitan dengan reaksi efervesen, jika kadar air terlalu tinggi akan memicu terjadinya reaksi efervesen sehingga diperlukan kadar air yang rendah (Elfiyani, 2014).

Dari hasil uji anova pada tabel 3.1 diperoleh nilai $\mathrm{p} 0,000<0,05$ dan $\mathrm{f}$ hitung $52,79>$ f-tabel 3,89 , yang berarti terdapat perbedaan yang bermakna dari kadar air antara setiap formula. Perbedaan signifikan antara Formula dikarenakan semakin banyak penggunaan Natrium bikarbonat akan semakin meningkatkan kandungan lembab granul karena natrium bikarbonat merupakan senyawa yang sangat higroskopis, pada RH 85\% (RH ruangan) natrium bikarbonat akan dengan cepat mengadsorbsi air dan akan terdekomposisi dengan melepaskan karbon dioksida (Sheskey, 2006). Kelembaban udara harus dijaga karena bahan efervesen yang bersifat higroskopis memiliki kemampuan menyerap udara menyebabkan reaksi iritasi dan tidak stabil tingkat kelembabannya (Aslani, 2013).
Rata-rata hasil penyusutan volume guncang menunjukkan formula I $9 \%$, formula II $4,44 \%$ dan formula III $3,25 \%$. Hasil uji volum guncang ini menunjukan granul tersebut akan mencapai kumpulan yang terpadat tanpa perubahan bentuk dari partkelnya setelah penyusutan yang artinya $<10 \%$ sesuai persyaratan (Elfiyani, 2014).

$$
\text { Pada tabel } 3.1 \text { uji Anova }
$$
volume guncang didapatkan nilai $\mathrm{p}$ $0,000<0,05$ dan f-hitung 33,93 > ftabel 3,89 yang berarti terdapat perbedaan yang bermakna antara formulasi terhadap volume guncang. Hal tersebut dikarenakan formula II dan III mengandung lebih banyak konsentrasi asam tartarat daripada Formula I yang menjadikan granul memiliki densisitas yang tinggi dan lebih padat dan tidak rapuh. Formula I juga memiliki konsentrasi sukrosa yang paling tinggi, sukrosa akan mudah rapuh pada kadar air yang rendah mengakibatkan granul yang terbentuk menjadi lebih rapuh.

Granul yang dapat mengalir dengan baik dan bebas dimaksudkan untuk dikempa dengan baik menjadi sediaan tablet, namun dalam hal ini pengujian yang dilakukan lebih dimaksudkan untuk melihat derajat kekeringan dari granul tersebut. Dari ketiga formula menunjukkan uji sifat aliran dengan hasil yang baik, kerena memiliki nilai waktu alir > 10 gram/detik yautu formula I 16,37 
gram/detik, formula II 22,37 gram/detik dan formula III 25,92 gram/detik yang artinya Formula III memiliki nilai waktu alir yang paling baik karena memiliki daya alir yang paling besar. Waktu alir dipengaruhi oleh bentuk, ukuran, porositas, densitas, gaya elektrostatika, dan gaya gesek partikel serta kondisi percobaan.

Tabel 4.15 dapat dilihat nilai $\mathrm{p}$ value yang didapat adalah $0,000<0,05$ dan f-hitung 18,20 > f-tabel 3,89 yang artinya terdapat perbedaan yang signifikan pada waktu alir antara ketiga formula. Perbedaan tersebut dikerenakan konsentrasi asam tartarat pada Formula II dan III lebih besar, asam tartrat mempunyai densitas yang lebih besar dengan massa $1,76 \mathrm{~g} / \mathrm{cm}^{3}$ dari asam sitrat $\left(1,542 \mathrm{~g} / \mathrm{cm}^{3}\right)$ atau sukrosa $\left(0,60 \mathrm{~g} / \mathrm{cm}^{3}\right)$ sehingga granul yang mengandung asam tartarat lebih banyak akan mempunyai densitas yang lebih besar. Densitas yang lebih besar, bobot molekul akan lebih besar sehingga akan semakin mudah mengalir karena gaya gravitasi yang lebih besar (Anshory, 2007).

Pada pengujian waktu dispersi digunakan penetrasi air untuk melarutkan granul efervesen menyebabkan terjadinya reaksi pada asam dan basa yang kemudian menghasilkan $\mathrm{CO}_{2}$ dan mengakibatkan hancurnya granul effervescent. Waktu larut merupakan salah satu sifat fisik sediaan efervesen yang khas, yaitu untuk melihat apakah semua bahan tercampur secara homogen serta melihat keefektifan pemilihan proses granulasi, dimana sediaan efervesen yang baik memiliki waktu larut selama $<5$ menit.

Dari hasil rata-rata uji waktu dispersi formula 1 selama 78 detik, formula II 56 detik dan formula III 45 datik. Uji waktu dispersi reaksinya selesai dalam waktu tidak lebih dari 5 menit dengan warna larutan kuning jernih, dengan hasil uji tersebut maka waktu dispersi granul efervesen ekstrak daging buah labu kuning ini memenuhi persyaratan uji waktu dispersi. Hasil tersebut menandakan bahwa jumlah perbandingan molekul asam sitrat, asam tartrat dan natrium bikarbonat serta bahan-bahan lain memiliki kesetimbangan yang sesuai persyaratan.

Pada tabel 4.20 uji Anova menujukkan nilai p $0,000<0,05$ dan $\mathrm{f}$ hitung 27,26 > f-tabel 3,89 yang artinya terdapat perbedaan antara ketiga formula terhadap waktu dispersi. perbedan tersebut dikarenakan Formula I memiliki waktu dispersi yang lama.

Formula I memiliki waktu dispersi yang paling lama dikarenakan formula I memiliki bahan tambahan yang paling banyak sehingga reaksi yang terjadi antara natrium bikarbonat, asam sitrat dan asam tartarat lebih lambat menuju kesetaraan. Lambatnya waktu dispersi pada Formula I juga dikarenakan Formula I memiliki konsentrasi asam tartarat paling kecil, Asam sitrat memili kelarutan lebih rendah dibanding asam tartarat, sehingga asam tartrat lebih cepat larut dibanding asam sitrat (Candra, 2008).

Nilai $\mathrm{pH}$ memiliki peranan penting dalam kehidupan sehari-hari dan perludipantau bagi kontrol kualitas produk farmasi, kosmetik, dan makanan (Schaude., 2017). Granul efervesen ekstrak daging buah labu kuning yang dihasilkan bersifat sedikit asam dengan $\mathrm{pH}$ formula I 6,31, formula II 6,03 dan formula III 5,31, karena pada uji normalitas data hasil uji $\mathrm{pH}$ tidak memenuhi persyaratan maka digunakan uji Kruskall-Wallis sebagai alternatif. Uji Kruskall-Wallis pada tabel 3.10 menunjukkan nilai $p$-value sebesar 0,002 yang artinya $<0,05$ dan f-hitung $12,82>$ f-tabel 3,89. Sehingga dapat disimpulkan bahwa terdapat perbedaan yang berarti pada setiap formulasi terhadap nilai $\mathrm{pH}$ granul efervesen. Hal tersebut dikarenakan perbandingan 
jumlah asam (Asam sitrat dan asam tartarat) pada formula I < formula II < formula III sehingga semua formula memiliki nilai $\mathrm{pH}$ yang berbeda-beda.

Pengamatan $\mathrm{pH}$ perlu dilakukan karena jika larutan efervesen yang terbentuk terlalu asam dapat mengiritasi lambung, sedangkan jika terlalu basa menimbulkan rasa pahit dan tidak enak. Berdasarkan derajat keasaman, bahan pangan dapat digolongkan kedalam tiga kelompok, yaitu (1) bahan panganberasam rendah dengan kisaran pH 5,3 sampai 4,5; (2) bahan pangan berasam sedang dengan kisaran $\mathrm{pH} 4,5$ sampai 3,7 dan (3) bahan pangan berasam tinggi dengan nilai $\mathrm{pH}$ dibawah 3,7 (Kailaku, 2012).

Dari data yang diperoleh dapat dikatakan bahwa ketiga formula granul memiliki nilai $\mathrm{pH}$ larutan yang telah memenuhi syarat dan termasuk golongan bahan pangan berasam rendah. Salah satu faktor yang dapat mempengaruhi keasaman $\mathrm{pH}$ adalah pembentukan $\mathrm{CO}_{2}$ pada saat terjadi reaksi reaksi effervescing dalam air yang sebagian akan larut membentuk asam karbonat. Asam karbonat ini kemudian mengurai menghasilkan ion $\mathrm{H}^{+}$dalam larutan yang menyebabkan keasaman pada larutan (Sandrasari, 2011).nilai $\mathrm{pH}$ paling baik adalah $\mathrm{pH}$ granul efervesen Formula I. Formula I memiliki $\mathrm{pH}$ yang rendah atau mendekati netral karena komponen asam yang digunakan paling sedikit dibanding dua formula yang lain.

\section{SIMPULAN}

Simpulan dari penelitian ini adalah ada pengaruh variasi konsentrasi asam sitrat, asam tartrat dan natrium bikarbonat terhadap kadar air granul efervesen dengan nilai p-value 0,000 dan f-hitung $52,79>$ f-tabel 3,89, konsentrasi natrium bikarbonat memiliki pengaruh yang paling signifikan terhadap kadar air dengan nilai t-Hitung 2,367 > t-Tabel 2,200. Ada pengaruh variasi konsentrasi asam sitrat, asam tartrat dan natrium bikarbonat terhadap volume guncang granul efervesen dengan nilai $\mathrm{p}$-value 0,000 dan f-hitung 43,17>t-tabel 3,89, konsentrasi asam tartarat memiliki pengaruh yang paling signifikan terhadap volume guncang dengan nilai t-Hitung 3,468 > t-Tabel 2,200. Ada pengaruh variasi konsentrasi asam sitrat, asam tartrat dan natrium bikarbonat terhadap waktu alir granul efervesen dengan nilai p-value 0,000 dan f-hitung $18,20>$ f-tabel 3,89, konsentrasi asam tartarat memiliki pengaruh yang paling signifikan terhadap waktu alir granul dengan nilai t-Hitung 2,378 > t-Tabel 2,200. Ada pengaruh variasi konsentrasi asam sitrat, asam tartrat dan natrium bikarbonat terhadap waktu dispersi granul efervesen dengan nilai $\mathrm{p}$-value 0,000 dan f-hitung 27,26 > f-tabel 3,89, konsentrasi asam tartarat memiliki pengaruh yang paling signifikan terhadap waktu dispersi granul dengan nilai t-Hitung 2,848> t-Tabel 2,200. Ada pengaruh variasi konsentrasi asam sitrat, asam tartrat dan natrium bikarbonat terhadap kadar air granul efervesen dengan nilai p-value 0,002 dan f-hitung $12,82>$ f-tabel 3,89, konsentrasi asam tartarat memiliki pengaruh yang paling signifikan terhadap $\mathrm{pH}$ dengan nilai t-Hitung 3,859 $>$ t-Tabel 2,200.Sediaan granul efervesen ekstrak labu kuning (Cucurbita maxima Durch) memiliki kualitas fisik meliputi kadar air, volume guncang, daya alir granul, waktu dispersi dan $\mathrm{pH}$ yang memenuhi kriteria sediaan granul efervesen.

Sebaiknya penelitian ini tidak hanya dibuat dalam bentuk sediaan granul efervesen saja tapi dapat dikembangkan dalam bentuk tablet efervesen yang dilanjutkan dengan uji bioavailibilitas dan uji toksikologi. 


\section{DAFTAR PUSTAKA}

Alam, M., N., Bristi, N. J., Rafiquzzaman, M., (2013), Review On In Vivo and In Vitro Methods Evaluation of Antioxidant Activity, saudi pharmaceutical, 2(21):143152.

Anonim. (2000). Parameter Standard Umum Ekstrak Tumbuhan Obat. Departemen Kesehatan RI Dirjen POM: Jakarta.

Ansel, H.C. (2005). Pengantar Bentuk Sediaan Farmasi Edisi IV. UI Press: Jakarta.

Aukkanit,N., Sirichokworrakit, S., (2017), Effect Of Dried Pumpkin Powder On Physical, Chemical, And Sensory Properties Of Noodle, International Journal Of Advances In Science Engineering And Technology, 5(1):14-18.

Aslani, A dan F, Fattahi, (2013), Formulation, Characterization and Physicochemical Evaluation of Pottasium Citrate Effervescent Tablets, Adv Pharm Bull, 3:217-25.

Candra, D., (2008), Pengaruh Variasi Konsentrasi Asam Tartarat Terhadap Sifat Fisik Dan Respon Rasa Tablet Effervescent Ekstrak Tanaman Ceplukan (Physalis Angulata L), Skripsi, Fakultas Farmasi, Universitas Muhammadiyah Surakarta: Surakarta.

Elfiani, R., Radjab, Naniek S. Harfiyyah, Luvi S., (2014), Perbandingan Penggunaan Asam Sitrat dan Tartarat Terhadap Sifat Fisik Granul Effervescent Ekstrak kering Kulit Buah Manggis (Garcinia Mangostana L), Jurnal Media Farmasi, 11(1):7-17.
Kumar, S., (2014), The Importance of Antioxidant And Their Role in Pharmaceutical Science - A Review , Asian Jurnal of Research in Chemistry and Pharmaceutical Sciences. 1(1): 27-44.

Lechman, (1989). Teori dan Praktek Farmasi Industri. Jilid II dan III. Terjemahan Suyatmi. Universitas Indonesia: Jakarta.

Lestari, P.M, Radjab, N.S, dan Octaviani, A., (2014), Formulasi dan evaluasi fisik granul effervescent sari buah naga (Hylocereus undatus), Farmasains, 2(4): 182-185.

Palobo, F.N., Yamelan, P.V.Y., dan Yudistira, A., (2012), Formulasi granul effervescent ekstrak dauk leilem (Clerodendrum minahassae $L$ ), Farmasi FMIPA UNSRAT, Makassar.

Parikh DM. (2015), Handbook of Pharmaceutical Granulation Technology. Taylor \& Francis Group: London.

Pisoschi, A., M. dan Negulescu, G., P., (2011), Method For Total Antioxidant Activity Determination: A Review, Biochem and Anal Biochem, 1(1):1-10.

Respati, A.N., (2010). Pengaruh penggunaan pasta labu kuning (Cucurbita moschata) untuk Subtitusi Tepung Terigu Dengan Penambahan Tepung Angkak Dalam Pembuatan Mie Kering, Skripsi, Fakultas Pertanian Universitas Sebelas Maret: Surakarta.

Riaz, S., Malook, S., Shah, A., H., Sarfaraz, M., Kazmi, S., M., Z., Abad, Z., jabeen, S., Uz Zaman, R., Q., asif, M., Ali, Q., (2005) Improvement of Secondari Metabolites for Cucurbita Moschata 
Through Tissue Culture Tecniques: An Overview, Life Science Jurnal,12(4):96-132.

Schaude, C., Frohlich, E., Meindl, C., Attard, J., Binder, B., Mohr, G.J. (2017) The Development of Indicator Cotton Swabs for the Detection of $\mathrm{pH}$ in Wounds. Sensors, 17(6):455-460.

Sheskey, P. J., Rowe, C.R., Owen, S.C., (2006), Handbook of Pharmaceutical Excipient, Pharmaceutical Press: London.

Siregar, C., dan Wikorso, Soleh.(2010).Teknologi Farmasi
Sediaan Tablet Dasar-Dasar Praktis. Buku Kedokteran EGC: Jakarta.

Voight, (1995). Buku Ajar Teknologi Farmasi. UGM press: Yogyakarta

Yulia, S.R. (2014). Perbandingan Metode Ekstraksi dan Variasi Pelarut Terhadap Rendemen dan Aktivitas Antioksidan Ekstrak Kubis Ungu (Brassica oleracea L. var. capitata f. rubra).Skripsi, Fakultas Farmasi Universitas Gadjah Mada: Yogyakarta. 